університету ім. М. П. Драгоманова. - К., 2002. - Випуск 7. - С. 3-16. 4. Добрович А. Б. Общение: Наука и искусство / А. Б. Добрович. - М. : Знание, 1978. - 143 с. 5. Калмыкова 3. И. Продуктивное мышление как основа обучаемости :[монография] / Зинаида Ильинична Калмыкова. - М.: Педагогика, 1981. - 200 с. 6. Краевский В. В. Теоретические основы профессионального становления молодого педагога / Володар Викторович Краевский. - Самара: СГПУ, 1996. - 167 с. 7. Найденов М. И. Творческий рефлексивно-групповой тренинг / М. И. Найденов, Л. А. Найденова // Интеллектуальные системы и творчество. Новосибирск. - 1991. - С. 86-98. 8. Сиротенко А. Й. Географія України :[пробний підруч. для 9 кл. середн. шк.] / А. Й. Сиротенко, Б. О. Чернов, В. Я. Плахута. - К. : Освіта, 1994. - 223 с. 9. Топузов О. М. Загальна методика навчання географії:[підручник] / О. М. Топузов, В. М. Самойленко, Л. П. Вішнікіна. - . : ДНВП «Картографія», 2012. - 512 с.

УДК 371.315.6:7.01

Ірина Могілей

\title{
ХУДОЖНЬО-ЕСТЕТИЧНЕ ВИХОВАННЯ СТАРШОКЛАСНИКІВ ЗАСОБАМИ СУЧАСНОЇ ПОПУЛЯРНОЇ МУЗИКИ
}

Могілей I. В. Художньо-естетичне виховання старшокласників засобами сучасної популярної музики.

У статті розглянуто сучасні тенденції викладання художньої культури у старшій школі. На основі аналізу й узагальнення наукової інформації уточнюється сутність дефініцій «естетичне виховання», «художнє виховання», «сучасна популярна музика» в аспекті мистецької освіти. Запропоновано форми й методи художньо-естетичного виховання з використанням сучасної популярної музики.

Ключові слова: естетичне виховання, художнє виховання, мистецька освіта, сучасна популярна музика, урок художньої культури, форми і методи художнього навчання.

Могилей И. В. Художественно-эстетическое воспитание старшеклассников средствами современной популярной музыки.

В статье рассмотрены современные тенденции преподавания художественной культуры в старшей школе. На основе анализа и обобщения научной информации уточняется сущность дефиниций «эстетическое воспитание», «художественное воспитание», «современная популярная музыка» в аспекте художественного образования. Предложены формы и методы художественно-эстетического воспитания с использованием современной популярной музыки.

Ключевые слова: эстетическое воспитание, художественное воспитание, художественное образование, современная популярная музыка, урок художественной культуры,формы и методы художественного обучения.

Mogiley I. V. Artistic and aesthetic education of senior pupils by means of modern popular music.

The article discusses the current trends of teaching art culture in high school. Based onthe analysisandsynthesis of scientific information specified entity definitions «aesthetic education», «art education», «modern popular music» in terms of art formation. Proposed forms and methods of art-aesthetic education with contemporary popular music.

Key words: aesthetic education, art education, art formation, modern popular music, a lesson of art culture, art forms and methods of training.

Кардинальні зміни у всіх галузях життя держави на початку XXI століття 
передбачають реформування загальноосвітньої школи на принципах демократизації, гуманізації, національної спрямованості освіти i виховання, що забезпечує соціокультурне становлення юних громадян. У зв'язку з цим особливого значення набуває художньо-естетичне виховання учнів.

Задля розв'язання окресленої проблеми важливий пошук нових та сучасних засобів. Саме таким засобом педагогічного впливу на учнів в умовах загальноосвітньої школи $є$ використання сучасної популярної музики. Керівництво процесом виховання і навчання старшокласників засобами сучасної популярної музики,полягає в тому, щоб допомогти учням навчитися цінувати прекрасне у всьому спектрі музичного мистецтва. Водночас існують суперечності між необхідністю навчання, орієнтованого на виховання особистості засобами сучасної популярної музики і відсутністю відповідних, достатньо обгрунтованих дидактичних матеріалів; потребою розуміння сутності художньо-естетичного виховання i невизначеністю розроблення, обгрунтування складного динамічного процесу формування ставлення людини до мистецтва. Визначені суперечності складають сутність обраної нами проблеми.

Mema cmammi- висвітлення сучасних тенденцій художньо-естетичного виховання учнів старшої вікової категорії з використанням сучасної популярної музики на уроках художньої культури.

Проблема естетичного виховання розглядалася досить глибоко у дослідженнях видатних філософів, психологів, педагогів (Арістотель, Піфагор, Геракліт, Б. Лихачов, В. Лозовий, О. Наконечна, С. Столович, В. Сухомлинський, Н. Чібісова, О. Шило, Д. Ельконін). Так, ще Аристотель зазначав, що у вихованні провідну роль має відігравати прекрасне, прагнення до однієї лише корисності обертається для держави великими втратами, а для конкретної особистості- невихованістю всього, що необхідно для життя [1, с. 32-34]. Піфагор проблему краси пов'язував з гармонією, яка для нього поєднувалася з досконалістю [11, с. 7-15].

Основною парадигмою, що визначає сутнісний зміст естетичного виховання, $€$ формування естетичної сфери особистості. Естетичне виховання О. Колеснікова, В. Лозовий розглядають як складну суспільно-педагогічну систему, яка є основою загальної духовної культури людини. Під естетичним вихованням вони розуміють цілеспрямований, організований і контрольований педагогічний процес формування естетичної свідомості особистості, розвиток емоційно-почуттєвої сфери та художньо-творчої діяльності [11, с. 25].

Різновидом виховання $є$ художнє виховання, яке визначається як процес формування в учнів здатності відчувати, розуміти, любити й оцінювати мистецтво, насолоджуватися ним і створювати художні цінності [8, с. 170]. Специфічною задачею художнього виховання є виховання художньої сприйнятливості, емоційного відгуку на художні цінності, формування художнього почуття та смаку, художніх поглядів та ідеалів особистості.

Порівнюючи естетичне і художнє виховання, слід зазначити, що ці два різновиди виховання не збігаються, але взаємодоповнюють одне одного. Естетичне виховання спрямоване на формування ставлення до навколишнього світу, природи, мистецтва, інтер'єру тощо, а художнє виховання - тільки до мистецтва. Проте мета художнього виховання $є$ також естетичною. Як зазначає А. Артоболевська, мета художнього виховання - викликати в кожному учневі віру в мистецтво як засіб вираження відповідно до його індивідуальних нахилів і потреб. При цьому художнє виховання не повинне орієнтуватися на найбільш обдарованих учнів; це виховання, що не має спеціалізації й передбачає розкриття в кожному індивідуумі потенційних 
можливостей [5, с. 11].

Важливе значення для організації художньо-естетичного виховання школярів мали питання психічного розвитку особистості, які розробляв Л. Виготський. У своїй монографії «Психологія мистецтва» науковець назвав мистецтво одним із найбільш ефективних засобів розвитку творчого потенціалу людини, обгрунтував особливості впливу художньої культури на суспільство і становлення особистості. Він уважав, що художня культура сприяє розвитку естетичної думки і творчої діяльності людини, а естетичні погляди, у свою чергу, формують світогляд, мораль та встановлюють норми суспільства [3].

Важливість мистецтва у вихованні учнів підкреслював А. Луначарський. На його думку, художнє виховання слід розуміти не як викладання будь-якого спрощеного мистецтва, а як систематичний розвиток почуттів і творчих здібностей, які розширюють можливості творення і милування красою [10, с. 19]. Найяскравіше ці думки виявились у музично-педагогічній діяльності . Асаф'єва, Б. Яворського, В. Шацької, які зіткнулися $з$ проблемою художньо-естетичного виховання на практиці. Розробляючи зміст і форми художньої освіти, педагоги великого значення надавали тому, як розповідати учням про художні твори і долучати їх до різноманітної творчої діяльності, як зберегти в художній культурі класичну спадщину.

Нові принципи та методи викладання музичного мистецтва в загальноосвітній школі визначив композитор, науковець і педагог Б. Асаф'єв. Велику увагу він приділяв формам розкриття дітям музичних творів, манері розповіді про композиторів. Науковець також спрямовував увагу педагогічної громадськості на позакласну роботу, яка засобами лекційного і концертного просвітництва, а також засобами організації художньої самодіяльності мала систематично долучати учнів до активної участі в музичній діяльності [2, с. 28].

Під впливом досягнень у галузі генетики та біології сформував свою теорію естетичного виховання відомий науковець i педагог у галузі образотворчого мистецтва О. Бакушинський, який висунув ідею про онтогенетичний розвиток художніх здібностей і розкрив взаємозв'язок між дитячою творчістю і професійним мистецтвом. Цікавими в його теорії залишаються аналогії, проведені між розвитком дитячої образотворчої діяльності й етапами розвитку світового мистецтва, а також ідея органічного поєднання педагогічної роботи та естетичної діяльності учнів. Теоретичні розробки науковця знайшли практичне застосування в роботі дослідноекспериментальної школи «Дитяча творчість», а новаторські педагогічні методи збагатили теорію і практику сучасної педагогіки мистецтва [10, с. 20].

Тотожні й надзвичайно важливі для сучасної педагогіки мистецтва погляди висловив відомий мистецтвознавець і педагог Ф. Шміт. У роботі «Мистецтво як предмет навчання» він запропонував оригінальну систему естетичного виховання засобами мистецтва, практичну реалізацію якої уважав невідкладним і актуальним завданням. Науковець звернув увагу читачів на необхідність спиратися на психологічні та фізіологічні особливості учнів під час викладання різних видів мистецтва. «Завдання естетичного виховання, - писав Ф. Шміт, - полягає не в тому, щоб навчити техніці в будь-якому виді мистецтва, а в розвитку творчих потенцій, $\mathrm{i}$, передусім естетичного уявлення, асоціативного мислення, удосконалення емоційної сфери (почуттів, бажань, смаків) підростаючого покоління» [10, с. 21].

Педагог уважав, що програма естетичного виховання повинна передбачати художні твори, що мають багатий емоційний зміст. Окрім того, класична спадщина може допомогти виховувати естетичне ставлення до сучасної дійсності. Отже, 
Ф. Шміт у своїх педагогічних поглядах наголошував на творчому характері художньо-естетичного виховання i потребі долучення учнів до широкого кола мистецьких явищ.

Вагомий внесок у розроблення теорії та практики художньо-естетичного виховання здійснили своєю науково-педагогічною творчістю класики вітчизняної педагогіки А. Макаренко та В. Сухомлинський. Новаторство розроблених педагогами педагогічних систем полягає в тому, що вони спрямовані на максимальний розвиток морально-духовних і творчих сил дитини. В. Сухомлинський у своїх роботах постійно наголошував на значенні прекрасного в розвитку людини.

Визначальним моментом у його виховній системі стало прагнення сформувати в кожній дитині естетичний ідеал. «Думка і краса, - писав В. Сухомлинський, - йдуть поруч, підносячи й звеличуючи людину» [7, с. 415]. Автор був переконаний, що краса здатна відкривати перед людиною довкілля. Свою позицію він часто висловлював за допомогою таких формулювань: «через красиве до людяного», «від краси до шляхетності».

Зазначені вище ідеї вплинули на розвиток методології мистецької освіти, яку розробляли науковці- мистецтвознавці, психологи та педагоги (О. Апраксіна, Н. Ветлугіна, Н. Гродзенська, Д. Кабалевський, Б. Ліхачов, О. Мелік-Пашаєв, Б. Неменський, М. Румер, Н. Сац, Б. Теплов). Вони обстоювали думку про доцільність виховання учнів на основі гармонійного поєднання процесів сприймання мистецтва i власної творчості. Ці ідеї відомих науковців також стали підгрунтям для розроблення теорії мистецької освіти на культурологічних засадах.

Незважаючи на великий обсяг наукових досліджень, присвячених проблемі художньо-естетичного виховання учнів, недостатнім залишається вивчення питання використання сучасної популярної музики у практиці викладання мистецьких дисциплін у загальноосвітній школі.

Нині терміном «популярна музика» зазвичай позначають: 1) усі явища музики; іноді 2) усілякий взірець музики загалом, який має популярність. У першому випадку зміст поняття «популярна музика» охоплює такі складники: легка оркестрова музика, пісні протесту, лірико-романтичні пісні, джаз, диско тощо. У другому - цим терміном позначають також і взірці класичної, опереточної, народної музики, що мають популярність.

Терміном же «поп-музика» позначається низка явищ в естрадній музиці, що мають яскраво комерційний характер. Це музика, яка безпосередньо включена в систему функціонування засобів масової інформації й індустрії аудіо- та відеозапису. Отже, якщо поняття «популярна музика» можна описати як музику будь-якого типу, що має популярність в масах (акцентуючи при цьому «популярність»), то поняття «поп-музика» визначає масову популярну музику, де акцент робиться на слові «масова», що передбачає іiі тиражування (у вигляді матеріальних носіїв музичних творів - CD-дисків, аудіо- та відеозаписів) і комерційні способи розповсюдження.

Як зазначає А. Сохор, масовою вважається загальнодоступна, загальнопоширена музика, адресована найширшим колам слухачів. Поширеність масової музики зумовлена іiі функцією «осуспільнення» почуттів людей і відповідаєпотребам масового суспільства в мистецтві. Це дозволяє характеризувати масову музику як художнє й соціальне явище. Сприйняття масової музики відбувається на активному (концерт, відеокліп, ефір) та пасивному (реклама, спортивні змагання) рівнях [4, с. 416].

Музика масових жанрів більш активно споживається слухачами, але естетичні властивості іï мають відносно невисокий рівень. Проте вона доступна за формою та 
змістом, близька до повсякденного життя людини, уже набула широку аудиторію, яка ще, на жаль, не здатна об'єктивно оцінити якість прослуханої музики. Тому основне педагогічне завдання полягає в тому, щоб допомогти учням навчитися цінувати прекрасне у спектрі музичного розмаїття.

Стан сучасної музичної культури суспільства, окремих категорій масової музики набув висвітлення в дослідженнях науковців-соціологів О. Семашко, А. Сохора, У. Суни, В. Цукермана, Т. Чередниченко та інших. Як зазначає більшість дослідників, на художньо-естетичне виховання підростаючої особи нині істотний уплив здійснює саме «масова» музична культура.

«Масова музична культура»- це явище специфічне, iї образ формується переважно під упливом позамузичних тимчасових чинників, наприклад, таких, як мода, стиль життя тощо. Не випадково музикознавцями відзначається цілком інший принцип образної структури в масових музичних напрямах, жанрах, особливі умови їхнього виконання і сприйняття. Саме масова музична культура $є$ сполучною ланкою між стабільним і мінливим у музичному мистецтві, тому що вона зорієнтована на цінності й норми переважної більшості глядачів і слухачів. Вона $\epsilon$ продуктом новітнього часу, затребувана до життя людиною, яка з різних причин не долучилася до класичної музичної культури [4, с. 417].

Зміст масової музичної культури складають різноманітні явища від кітчу (творів, розрахованих на миттєвий, швидкоплинний успіх) і кемпу («естетизованого кітчу», С. Стукалова) до складних, змістовно насичених форм. До останніх належать окремі види рок-музики, поп-арт (від англ.: «popular art»- загальнодоступне мистецтво) течія сучасного мистецтва, у якій випадковими засобами поєднуються побутові предмети, механічно тиражовані копії, уривки друкованих видань тощо. Проте кращі твори, що створені в жанрах масової музики, можуть бути і високохудожніми, i змістовними, а також містити виховний потенціал. Тому роль їх у сучасній музичній культурі не варто недооцінювати. Більше того, у цій галузі спостерігаються справжні шедеври музичного мистецтва, тому важливо використовувати їх у сучасній педагогічній практиці. При цьому вчителю треба самому орієнтуватися в жанровому, стильовому розмаїтті поп- і рок-музики, джазу.

Сучасна музика масових жанрів - продукт, який активно споживається учнями, естетичні характеристики якого мають відносно суб'єктивний характер упливу. Головне, щоб старшокласник уже набув певного емоційно-естетичного досвіду, щоб у нього була сформована здатність до узагальнення явищ довкілля, життя і культури. Тому під час сприйняття й виконання творів сучасної популярної музики вихованець намагається самостійно оцінити зміст і якості музичного твору за вже відомими йому критеріями. Наявність різноманітних стилів і напрямів музики вказує на те, що кожний iз них має власний еталон для їх адекватної аксіологічної оцінки, але універсальним критерієм оцінки музичних явищ $є$ їх моральна, пізнавальна й естетична цінність. Учитель повинен допомогти учням оволодіти критеріями оцінки музичних творів $\mathrm{i}$ формувати у них ціннісні орієнтації в галузі музичної культури [4, с. 422].

Сучасна класична музика, джаз і рок- три головні галузі музичної культури другої половини ХХ століття. Важливою галуззю музичного життя цього періоду стала і поп-музика - складний комплекс популярних музичних напрямів та індустрії розваг. У класиці, джазі й рок-музиці $є$ загальний корінь- традиції фольклору. Система мислення, закладена в стародавньому фольклорі, виявилася співзвучною трагічному духовному досвіду сучасної людини. Пошуки в цьому напряму серйозно вплинули на виникнення у 50-х рр. рок-музики - явища, що перевернуло в короткий термін музичний світ. Надати визначення рок-культурі надзвичайно важко, оскільки 
йдеться про особливий спосіб життя в музиці, у якому об'єдналися композиторська творчість й імпровізація, музика і сценічна дія, живе звучання чи голос інструмента і складні ефекти електронної техніки. Виникнувши під упливом фольклору, ця культура ніколи не пов'язувала себе з конкретними національними традиціями: мова року інтернаціональна і спрямована на об'єднання людей різного походження та світогляду. Провідна роль у рок-музиці належить психологічному й емоційному впливу, що виходить часом від одного слова чи звука. Величезне значення має вплив звукової моці музики, психічний стан слухача, під час виступів, як правило, використовується складна звукопідсилювальна апаратура. Творчість музиканта неможлива поза колективом. Його учасники не лише виконують, але і часто складають музику разом. Проте на сцені кожний із них знаходить індивідуальні форми самовираження. У рок-музиці, як у дзеркалі, відбилися потрясіння, через які пройшли післявоєнні покоління молоді: стихійні соціальні виступи і «сексуальна революція», рух хіпі й панків, трагедія наркоманії і духовні пошуки.

Якщо рок-музика говорить від імені інтернаціональної аудиторії, то джазова культура тривалий час була голосом конкретного етнічного середовища - афроамериканського населення США. Вплив фольклорних традицій відчувається в ній ще сильніше, ніж у року. Джаз - теж спосіб життя. У його основі - імпровізація, що є для музиканта формою осягнення світу через звуки. Саме від джазу рок успадкував свої основні риси - потяг до імпровізації та колективних форм творчості. Проте на відміну від року джазова імпровізація розрахована на камерне, довірливе спілкування зі слухачем (навіть в умовах величезного концертного залу). Від публіки джазовий музикант не чекає на фанатичне обожнювання (на що нерідко претендує рокмузикант), а зріле розуміння, не на сплеск емоцій, а занурення в щиросердечний світ виконавця. Джазові музиканти виступають, як правило, в невеликих залах і клубах, прагнучи сформувати «свою» публіку й орієнтуючись на тонких знавців. Виникнувши більше століття тому, джаз переступив споконвічні етнічні межі. Нині це інтернаціональний вид творчості з безліччю регіональних і стильових різновидів.

Поп-музика - складний комплекс популярних музичних напрямів та індустрії розваг. Поп-музикою спочатку (50-ті - перша половина 60-х рp. XX ст.) називали і поп-, і рок-музику. Нині до поп-музики стали відносити розважальну музику, призначену для слухача з усередненим смаком. Вона заснована на напрямах, стилях $\mathrm{i}$ жанрах сучасної музики - рок-музики, соула, фанка, і в цьому іiі відмінність від популярної музики в широкому сенсі слова. 3-поміж нових та сучасних напрямів попмузики варто назвати диско (середина 70-х pp. XX ст.), брит-поп, напрями французької, італійської, російської та української поп-музики.

На сучасному етапі великий уплив на аудиторію поп-музикантів здійснюють численні музичні кабельні канали телебачення. Молодь усе більше звертає увагу на сюжет побаченого кліпу, ніж на музику і тексти пісень. Рок- і поп-музика нині мають приблизно однакову популярність серед молоді.

Зауважимо, що сучасна популярна музика, здійснюючи всебічний уплив на старшокласників, $є$ ефективним засобом художнього навчання на уроках мистецького циклу. Задля досягнення цієї мети вчителеві доцільно застосовувати методи бесіди, порівняння, зіставлення, емоційно-образної драматургії, художньо-педагогічного аналізу, створення проблемно-пошукових ситуацій, відеометод.

Здійснюючи художньо-естетичне виховання учнів, формуючи в них ціннісні орієнтації в галузі сучасної популярної музики, вчителям художньої культури варто проводити уроки 3 тем: «Музичні ритми Америки», «Луї Армстронг - золота ера джазу», «Класика і рок-музика - суперники і союзники», «Легенди світової рок- 
музики»,«Сучасна поп-музика України»та інші. Поряд із традиційними доцільно використовувати нетрадиційні форми уроків художньої культури - урок-«музичний портрет», урок-діалог, урок-інтерв'ю, урок-дискусія, урок-телеміст.

Художньо-естетичне виховання старшокласників відбувається під час виконання тестових завдань,демонстрації фрагментів відеофільмів, присвячених, наприклад, творчості Л. Армстронга, Е. Преслі, гурту «Бітлз», Е. Піаф, відеокліпів українських попзірок - представників сучасного естрадного шоу-бізнесу (В. Вакарчук, Джамала, А. Лорак, Руслана), а також під час виконання таких творчих завдань: 1) написати твірроздум «Моє ставлення до сучасної популярної музики»; 2) описати той джазовий твір, від сприйняття якого ви отримали найсильніше враження; 3) придумати назву переглянутого відеокліпу; 4) описати сприйняття улюбленого твору рок-музики; 5) написати твір-мініатюру на тему «Я - поп-зірка»; 6) провести інтерв’ю з «уявленою» зіркою естрадного шоу-бізнесу; 7) написати міні-рецензію на переглянутий відеокліп А. Лорак «Мальви»; 8) які асоціації виникають у Вас під час прослуховування рок-опери «Фантом опери» Е.Л. Уеббера?; 9) маючи повноваження міністра культури, які нововведення в галузі сучасної популярної музики Ви б запровадили? тощо.

Отже, художня культура є чинником впливу на художньо-естетичне виховання старшокласників, яке в навчальному процесі відбувається на достатньому матеріалі творів масової музичної культури. При цьому виховання учнів засобами сучасної популярної музики спрямоване не на вивчення теоретичних основ моралі, формування етичних уявлень і понять, а на активне оволодіння красою різножанрової музичної палітри, розвиток аксіологічних (моральних, пізнавальних, естетичних) орієнтацій у цій багатющій скарбниці національної та світової культури.

Сучасна популярна музика, як засіб педагогічного впливу, 3 урахуванням цілеспрямованого, систематичного й послідовного використання сприяє розвитку гармонійного поєднання різноманітних емоцій, асоціацій, накопиченню яскравих вражень, створенню власних художніх образів, уявлень про довкілля і $є$ підгрунтям художньо-естетичного виховання учнівської молоді.

Процес художньо-естетичного виховання старшокласників засобами сучасної популярної музики є актуальним і потребує подальшого теоретичного осмислення й апробації.

\section{Література}

1. Аристотель. Сочинения: в 4 т./ Аристотель. - М. : Мысль, 1975. - Т. 1.550 с. 2. Асафьев Б. В. Избранные статьи о музыкальном просвещении и образовании / Борис Владимирович Асафьев. - Л.: Музыка, 1973.- 144 с. 3. Выготский Л. С. Психология искусства : [монография]/Лев Семенович Выготский; под ред. М. Ярошевского. - М. : Педагогика, 1987. - 344 с. 4. Довідник учителя художньо-естетичного циклу в запитаннях та відповідях/[упоряд. М. С. Демчишин]. - Х. : Ранок, 2006. - 608 с. 5. Первые встречи с искусством: [книга для родителей] / Анна Дмитриевна Артоболевская. - М. : Ред. журнала «Искусство в школе», 1995. - 224 с. 6. Рудницька О. П. Музика і культура особистості: проблеми сучасної педагогічної освіти: [книга для вчителя] / Оксана Петрівна Рудницька. - К. : Либідь, 1988. - 164 с. 7. Сухомлинський В. О. Серце віддаю дітям: [монографія] / Василь Олександрович Сухомлинський. - К. : Рад. школа, 1977.359 с.8. Сухомлинський В. О. Як виховати справжню людину // Вибрані твори: в 5 т. / Василь ОлександровичСухомлинський. - К. : Рад. школа, 1976. - Т. 2. - 473 с. 9. Художественная культура: Понятия. Термины / [сост. Л. Дорогова]. - М. : Знание, 1978. - 208 с. 10. Щолокова О. П. Методика викладання світової художньої культури: [підручник] / Ольга Пилипівна Щолокова. - К. : НПУ ім. М. П. Драгоманова, 2007. - 194 с.11. Эстетика: [учеб. пособие]/ под ред. Е. В. Колесниковой, 
В. А. Лозового, Н. Г. Чибисовой, А. В. Шило. - Сумы: Университет, 1999. - 304 с.

УДК 373.5.016:91

Свімлана Тросюк

\section{РОЗРОБЛЕННЯ КРАЇНОЗНАВЧОГО СКЛАДНИКА У ЗМІСТІ ПРЕДМЕТНОЇ КОМПЕТЕНТНОСТІ УЧНІВ ОСНОВНОЇ ШКОЛИ}

Тросюк С. Д. Розроблення країнознавчого складника у змісті предметної компетентності учнів основної школи.

У статті розкрито алгоритм формування країнознавчих понять у змісті предметної компетентності учнів основної школи. Наведено приклади роботи 3 географічними i країнознавчими поняттями на рівні зіставлення i системних взаємозв'язків. Країнознавчий складник розглядається як фоновий у процесі формування географічної компетентності учнів основної школи під час вивчення географії України.

Ключові слова:учні основної школи, предмети природничого циклу, країнознавчий складник, географічна компетентність, географічні поняття, країнознавчі поняття.

Тросюк С. Д. Разработка страноведческого компонента в содержании предметной компетентности учащихся основной школы.

В статье раскрыт алгоритм формирования страноведческих понятий в содержании предметной компетентности учащихся основной школы. Приведены примеры работы с географическими и страноведческими понятиями на уровне сопоставления и системных взаимосвязей. Страноведческая составляющая рассматривается как фоновая при формировании географической компетентности учащихся основной школы в процессе изучения географии Украины.

Ключевые слова: учащиеся основной школы, предметы естественного цикла, страноведческая составляющая, географическая компетентность, географические понятия, страноведческие понятия.

Trosyuk S. D. Development of regional studies component in the content of geographical competence of primary school pupils.

This article deals with an algorithm of forming geographic concepts in the sense of geographical competence of primary school pupils. Providesexamples of the geographic and regional concept level matching and system interconnections. Geographic component is considered as a background in the formation of geographical competence of primary school students in the study of the geography of Ukraine.

Keywords: primary school pupils, subjects of natural sciences, geographic component, geographical expertise, geographic concepts, geographic concepts.

Новітня концепція освіти визначає складником державних освітніх стандартів компетентність того, хто оволодіває освітою. За основну мету середньої школи ставиться виховання й навчання людини, здатної до культурного творіння й продуктивного діалогу 3 соціумом, яка володіє необхідними для здійснення навчальної і практичної діяльності знаннями, уміннями і навичками, тобто успішного розв'язання предметних завдань, що дає змогу бути обізнаним у справах певної галузі, кваліфіковано розв'язувати питання сфери діяльності.

Основні складники методики формування предметної компетенції, пов'язані 3 уведенням їх, складанням визначень і розкриттям суттєвих та несуттєвих ознак, а також іiі розвитком під час практичного застосування, виявлено у дослідженнях вітчизняних і зарубіжних педагогів, зокрема: Ю. Бабанського, І. Беха, С. Гончаренка, Г. Ковальчук, В. Кременя, В. Краєвського, О. Пометун, М. Поташника, Н. Тализіної, 174

Педагогіка вищої та середної школи. - 2014. - Вип. 41 